\title{
Obesity - a risk factor for postoperative complications in general surgery?
}

\author{
Elke E.K.M. Tjeertes ${ }^{*}$, Sanne S.E. Hoeks ${ }^{1}$, Sabine S.B.J.C. Beks², Tabita T.M. Valentijn' ${ }^{1}$, Anton A.G.M. Hoofwijk ${ }^{2}$ \\ and Robert Jan R.J. Stolker ${ }^{1}$
}

\begin{abstract}
Background: Obesity is generally believed to be a risk factor for the development of postoperative complications. Although being obese is associated with medical hazards, recent literature shows no convincing data to support this assumption. Moreover a paradox between body mass index and survival is described. This study was designed to determine influence of body mass index on postoperative complications and long-term survival after surgery.

Methods: A single-centre prospective analysis of postoperative complications in 4293 patients undergoing general surgery was conducted, with a median follow-up time of 6.3 years. We analyzed the impact of bodyweight on postoperative morbidity and mortality, using univariate and multivariate regression models.

Results: The obese had more concomitant diseases, increased risk of wound infection, greater intraoperative blood loss and a longer operation time. Being underweight was associated with a higher risk of complications, although not significant in adjusted analysis. Multivariate regression analysis demonstrated that underweight patients had worse outcome (HR 2.1; $95 \% \mathrm{Cl} 1.4-3.0$ ), whereas being overweight (HR 0.6; $95 \% \mathrm{Cl} 0.5-0.8$ ) or obese (HR 0.7; $95 \%$ $\mathrm{Cl}$ 0.6-0.9) was associated with improved survival.

Conclusion: Obesity alone is a significant risk factor for wound infection, more surgical blood loss and a longer operation time. Being obese is associated with improved long-term survival, validating the obesity paradox. We also found that complication and mortality rates are significantly worse for underweight patients. Our findings suggest that a tendency to regard obesity as a major risk factor in general surgery is not justified. It is the underweight patient who is most at risk of major postoperative complications, including long-term mortality.
\end{abstract}

Keywords: Obesity, Postoperative complications, Long-term survival, General surgery

\section{Background}

According to the World Health Organization, obesity has doubled since 1980, with a prevalence that is continuing to rise. In the United States, more than one-third of the adult population is currently obese [1]. As in Europe, obesity has also reached epidemic proportions, although with considerable geographic variation [2].

Being obese is associated with increased risk of a number of medical conditions, including diabetes, coronary artery disease, hypertension, hyperlipidemia and certain types of cancer [3]. Obesity reduces quality of life [4] and life expectancy itself [5-7]. However, recent studies

\footnotetext{
* Correspondence: e.tjeertes@erasmusmc.nl

${ }^{1}$ Department of anesthesiology, Erasmus University Medical Centre, Room $\mathrm{H}-1273$, PO Box 2040, 3000, CA, Rotterdam, The Netherlands

Full list of author information is available at the end of the article
}

show that, except for wound infections, complication rates are not increased in this group of patients [8-10]. Despite considerable investigation, the effect of different weight categories on all other types of postoperative complications and long-term survival remains controversial.

More recently a paradox between body mass index and survival is described in both cardiac and noncardiac surgical population [11-13]. This paradox shows an inverse relationship between body mass index and mortality, with lower mortality rates among the overweight and mild obese and increased mortality rates in the underweight population.

We hypothesized that a tendency to consider obesity as a major risk factor in general surgery, is not justified. Therefore, this study was designed to determine influence

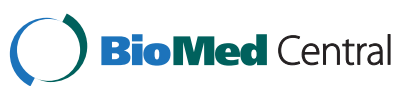

(c) 2015 Tjeertes et al. This is an Open Access article distributed under the terms of the Creative Commons Attribution License (http://creativecommons.org/licenses/by/4.0), which permits unrestricted use, distribution, and reproduction in any medium, provided the original work is properly credited. The Creative Commons Public Domain Dedication waiver (http:// creativecommons.org/publicdomain/zero/1.0/) applies to the data made available in this article, unless otherwise stated. 
of body mass index on postoperative complications and long-term survival after surgery.

\section{Methods}

\section{Study sample}

This study is a single-centre prospective analysis of postoperative complications in patients undergoing general surgery. We obtained data from all consecutive patients undergoing general surgery at our institution from March 2005 to December 2006. Since the beginning of 2005 this general teaching hospital contains a highly modern degree of automation and a reliable registration of the electronic medical record. All patients undergoing elective or urgent surgery within the mentioned study period were included. Exclusion criteria were procedures performed under local anesthesia, patients younger than 14 years old and assisting surgery for a specialism other than the surgery department (for example: a member of the surgical staff assisting in a gynecologic procedure). Bariatric surgery was not performed in this medical center. The study cohort consisted of 5030 procedures in 4479 patients. Because one of our primary endpoints is long-term survival, we decided to restrict our analyses to the patient's first operation only. When a patient needed repeated surgery during the same hospital stay, we did include the need for a reoperation as a separate outcome measure. Patients $(n=186)$ of whom height or weight were not available were excluded. Therefore, the study population consisted of 4293 patients. The study complies with the Helsinki statement on research ethics and due to the non-interventional character of this study; approval by the medical ethical committee at time of enrolment was not necessary according to Dutch law. Even though, the local medical ethical committee granted a formal statement of approval retrospectively.

\section{Baseline characteristics}

Before surgery all patients were seen by a surgeon or a surgical resident who collected the patient characteristics. Information was gathered about the patient's medical history such as pulmonary, cardiac or cerebrovascular disease, American Society of Anesthesiologists (ASA) classification, diabetes, hypertension, any malignancy, medication, intoxications and height and bodyweight. Pulmonary disease was defined as any illness of the lungs or respiratory system, such as asthma, lung cancer, chronic infections, previous pulmonary embolisms, or chronic obstructive pulmonary disease (COPD). Cardiac disease refers to coronary artery disease with or without previous intervention, heart failure, arrhythmias, valvular heart disease or cardiomyopathy.

The Body Mass Index (BMI; $\mathrm{kg} / \mathrm{m}^{2}$ ) was used, according to the recommendation of the World Health Organization, as the measure to classify underweight, overweight and obesity in adults.

Patients with a body mass index $(\mathrm{BMI})>30 \mathrm{~kg} / \mathrm{m}^{2}$ were defined as obese and were compared to patients with underweight $\left(\mathrm{BMI}<18.5 \mathrm{~kg} / \mathrm{m}^{2}\right)$, normal weight (BMI $18.5-25 \mathrm{~kg} / \mathrm{m}^{2}$ ), and patients with overweight (BMI 25$30 \mathrm{~kg} / \mathrm{m}^{2}$ ) [1]. Furthermore, we collected surgery related characteristics. Surgical risk was divided into low, intermediate and high-risk procedures as proposed by Boersma et al. in their surgical risk classification system [14]. Secondly, we collected the type of anaesthesia, divided into loco regional (i.e. neuraxial or peripheral nerve blocks) or general anaesthesia. Finally we determined whether the patient was treated in an inpatient or outpatient surgical setting.

\section{Postoperative and long-term outcome}

Primary endpoints were complications within 30 days from surgery and long-term mortality. Patients were followed during hospital stay and during their visits to the outpatient clinic up to one year. To analyze the outcome we obtained the following data: length of hospital stay (LOS), blood loss, operating time and the presence of postoperative complications, e.g. wound infections, pneumonia, thromboembolic events, cardiovascular and cerebrovascular events, ICU-admission, readmission, the need for repeated surgery, as well as in-hospital mortality. For an objective interpretation of complications, we used a modified classification system proposed earlier by Clavien and Dindo, in order to increase uniformity in reporting outcome measures $[15,16]$. Concisely, the grade of complications is based upon five grades, according to severity of the problem. Grade I is a minor and self-limiting complication, not needing any specific treatment. A grade II complication needs specific drug therapy (such as antibiotics), or a minor treatment such as opening the wound at the patient's bedside, whereas a grade III complication needs invasive procedures such as percutaneous drainage of an abscess or repeated surgery. Grade IV are these complications with residual disability, including organ failure or resection. Finally grade V means the patient died due to his complications. Any event that deviated from a normal postoperative course was registered as a complication. Long-term survival was based on information from the national public register. All complications were independently graded by a surgical resident as well as a member of the surgical staff.

\section{Statistical analysis}

We presented categorical variables as numbers and percentages. Continuous variables were presented as mean \pm standard deviation (SD) when normally distributed, or as median and interquartile range (IQR) when data was skewed. A chi-square test was used for all categorical 
variables. Continuous variables were compared by using analysis of variance or the Kruskal Wallis test. In order to study the association between different BMI categories and postoperative complications, univariable and multivariable logistic regression models were used. Kaplan-Meier survival curves were calculated to assess the relation between the BMI categories and 5-year survival and compared with a log-rank test. The relation between BMI categories and long-term mortality was evaluated using multivariable Cox proportional hazard regression analysis. All potential confounders (age, gender, surgical risk, type of anesthesia, ASA classification, diabetes, hypertension, pulmonary -, cardiac -, or cerebrovascular disease and the presence of a malignancy) were entered in the multivariable model to ensure giving an unbiased as possible estimate in the regression models. Patients in different BMI categories were compared to those of normal weight. Results are reported as odds ratios (OR) or hazard ratios (HR) with a $95 \%$ confidence interval. For all tests, significance was set at a two-sided $P$-value $<0.05$. The statistical analyses were performed using SPSS, version 20.0.0 statistical software (SPSS Inc., Chicago, Illinois).

\section{Results}

\section{Patient population}

A total of 4293 patients were suitable for analysis, of which 1815 (42.3\%) were of normal weight, 100 (2.3\%) were underweight, 1635 patients $(38.1 \%)$ were overweight and 743 patients $(17.3 \%)$ were obese. Table 1 shows the baseline and surgery related characteristics of the study population.

When categorized by BMI, obese patients had more comorbidities, such as diabetes $(P<.001)$, hypertension $(P<.001)$, cardiovascular disease $(P=.006)$ and

Table 1 Baseline Characteristics

\begin{tabular}{|c|c|c|c|c|c|}
\hline & $\begin{array}{l}\text { Normal weight } \\
\text { BMI } 18.5-25(\mathrm{~kg} / \mathrm{m} 2) \\
(N=1815)\end{array}$ & $\begin{array}{l}\text { Underweight } \\
\mathrm{BMl}<18.5(\mathrm{~kg} / \mathrm{m} 2) \\
(N=100)\end{array}$ & $\begin{array}{l}\text { Overweight } \\
\text { BMI } 25-30(\mathrm{~kg} / \mathrm{m} 2) \\
(N=1635)\end{array}$ & $\begin{array}{l}\text { Obese } \\
\text { BMl > 30(kg/m2) } \\
(N=743)\end{array}$ & $p$ value \\
\hline \multicolumn{6}{|l|}{ Demographics } \\
\hline Age, years (mean $\pm S D$ ) & $53.7( \pm 18.9)$ & $51.6( \pm 21.6)$ & $57.0( \pm 15.5)^{a}$ & $55.5( \pm 14.9)^{\mathrm{a}}$ & $<0.001$ \\
\hline BMI (mean \pm SD) & $22.6( \pm 1.7)$ & $17.3( \pm 1.1)$ & $27.2( \pm 1.4)$ & $33.5( \pm 3.4)$ & $<0.001$ \\
\hline Male sex (\%) & $893(49.2 \%)$ & $39(39.0 \%)^{a}$ & $970(59.3 \%)^{\mathrm{a}}$ & $315(42.5 \%)^{a}$ & $<0.001$ \\
\hline ASA classification (\%) & & a & a & a & $<0.001$ \\
\hline । & 727 (40.1\%) & $31(31.3 \%)$ & $535(32.8 \%)$ & $135(18.2 \%)$ & \\
\hline$\|$ & $553(30.5 \%)$ & $20(20.2 \%)$ & $636(39.0 \%)$ & $362(48.8 \%)$ & \\
\hline III & $460(25.4 \%)$ & $39(39.4 \%)$ & $412(25.3 \%)$ & $223(30.1 \%)$ & \\
\hline IV & $72(4.0 \%)$ & $8(8.1 \%)$ & $47(2.9 \%)$ & $21(2.8 \%)$ & \\
\hline V & $1(<1 \%)$ & $1(<1 \%)$ & $0(0.0 \%)$ & $1(<1 \%)$ & \\
\hline \multicolumn{6}{|l|}{ Medical history (\%) } \\
\hline Diabetes mellitus & $86(4.7 \%)$ & $6(6.1 \%)$ & $162(9.9 \%)^{\mathrm{a}}$ & $134(18.1 \%)^{a}$ & $<0.001$ \\
\hline Hypertension & $257(14.2 \%)$ & $14(14.1 \%)$ & $360(22.1 \%)^{a}$ & $225(30.3 \%)^{a}$ & $<0.001$ \\
\hline Cerebrovascular disease & $123(6.8 \%)$ & $8(8.1 \%)$ & $118(7.2 \%)$ & $54(7.3 \%)$ & 0.919 \\
\hline Malignant disease & $451(24.9 \%)$ & $25(25.3 \%)$ & $362(22.2 \%)^{a}$ & $172(23.2 \%)$ & 0.308 \\
\hline Pathological cardiac history & $302(16.7 \%)$ & 18 (18.2 \%) & $316(19.4 \%)^{a}$ & $158(21.3 \%)^{a}$ & 0.033 \\
\hline Pathological pulmonary history & $261(14.4 \%)$ & $15(15.2 \%)$ & $205(12.6 \%)$ & $138(18.6 \%)^{a}$ & 0.002 \\
\hline Current smoking $^{b}$ & $490(35.4 \%)$ & $39(48.8 \%)^{a}$ & $374(30.4 \%)^{a}$ & $163(26.9 \%)^{a}$ & $<0.001$ \\
\hline Surgery risk (\%) & & a & & a & $<0.001$ \\
\hline Low & 1078 (59.4 \%) & $33(33.0 \%)$ & $969(59.3 \%)$ & 365 (49.1 \%) & \\
\hline Intermediate & $643(34.4 \%)$ & $52(52.0 \%)$ & $577(35.3 \%)$ & $350(47.1 \%)$ & \\
\hline High & $94(5.2 \%)$ & $15(15.0 \%)$ & $89(5.4 \%)$ & $28(3.8 \%)$ & \\
\hline \multicolumn{6}{|l|}{ Type of anesthesia (\%) } \\
\hline General & 1499 (82.8 \%) & $93(93.9 \%)^{a}$ & 1376 (84.3 \%) & $684(92.2 \%)^{a}$ & $<0.001$ \\
\hline \multicolumn{6}{|l|}{ Surgical setting (\%) } \\
\hline Outpatient surgery & $690(38.0 \%)$ & $22(22.0 \%)^{a}$ & 607 (37.1 \%) & $216(29.1 \%)^{a}$ & $<0.001$ \\
\hline
\end{tabular}

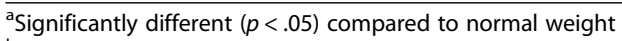

${ }^{\mathrm{b}}$ Data was available in $76.9 \%$ of patients 
pulmonary disease $(P=.010)$ than patients of normal weight. High-risk surgery was more often performed in the group of underweight patients $(n=15,15.0 \%)$, while in the obese group; the surgical risk was predominantly low or intermediate $(n=725,96.2 \%)$. Table 2 shows the use of cardiovascular and pulmonary medication at time of surgery.

\section{Postoperative complications}

Obesity resulted in a longer operation time $(P<0.001)$, more intraoperative blood loss $(P<0.001)$ and higher rates of surgical site infections $(P<0.001)$ (Table 3$)$. Underweight patients also had higher rates of complications than normal weight patients (Table 3). The overall mortality rate within 30 days was $1.2 \%$ (52 patients), with a disadvantage for underweight patients $(n=4$, $4.0 \%)$. Complication grades were different between groups, with more non self-limiting (>grade 1) complications in the underweight $(n=25,25 \%)$, overweight ( $n=277,16.9 \%)$ and the obese $(n=154,20.7 \%)$, compared to $14.2 \%(n=258)$ in normal weight patients (overall $P$-value $P<0.001$ ) (Fig. 1 and Additional file 1 ).

A multivariate regression analysis, adjusting for confounders, demonstrated that obesity was associated with a higher risk of postoperative complications (OR 1.3; $95 \%$ CI 1.1-1.7) (Table 4).

\section{Long-term survival}

Long-term survival was based on information from the national public register, available in 4218 patients (98.3\%), with a median follow-up time of 6.3 (interquartile range 5.8-6.8) years. Last available follow-up information was used for 93 patients $(2.2 \%)$ who lived abroad or had emigrated. A total of 687 patients (16.3\%) died during a follow-up of 6.3 (IQR 5.8-6.8) years, including the 52 patients who died within 30 days of first hospital admission. Figure 2 shows a Kaplan-Meier estimate of overall longterm survival. Six year survival estimates varied significantly among the different BMI-categories: $64.2 \%$ in the underweight group, $82.1 \%$ in the normal weight group, $87.1 \%$ in the overweight group and $86.6 \%$ in the obese group. Multivariate regression analysis, adjusting for confounders, demonstrated that underweight patients undergoing general surgery again had the worst outcome (HR 2.1; $95 \%$ CI 1.4-3.0), whereas being overweight (HR 0.6; $95 \%$ CI $0.5-0.8$ ) or obese (HR 0.7; $95 \%$ CI $0.6-0.9$ ) is associated with improved survival (Table 4).

\section{Discussion}

In this large sample of patients we found that obesity is a significant risk factor for surgical site infection, more surgical blood loss and a longer operation time, however these complications did not affect long-term survival. Our finding that the incidence of surgical site infection increases with an increase of BMI confirms previous studies [8, 17-19]. A couple of explanations can be given for this association. First of all, excessive subcutaneous fat tissue predisposes these patients to impaired healing due to low regional perfusion and oxygen tension [20]. Secondly, in our study there was an increase in operation time for the obese and a longer operation time has been described as a significant predictor of postoperative wound infections $[17,18]$. Furthermore impaired immunity, elevated blood glucose levels and too much tension on the surgical incision are also contributory factors to impaired wound healing $[21,22]$. Thus, with exception of the complications described earlier, there was no difference in risk of any major postoperative adverse event between the obese and patients of normal weight. Being overweight or obese was actually associated with improved 30 days

Table 2 Baseline Characteristics; Medication

\begin{tabular}{|c|c|c|c|c|c|}
\hline & $\begin{array}{l}\text { Normal weight } \\
\text { BMI } 18.5-25(\mathrm{~kg} / \mathrm{m} 2) \\
(N=1815)\end{array}$ & $\begin{array}{l}\text { Underweight } \\
\mathrm{BMI}<18.5(\mathrm{~kg} / \mathrm{m} 2) \\
(\mathrm{N}=100)\end{array}$ & $\begin{array}{l}\text { Overweight } \\
\text { BMl } 25-30(\mathrm{~kg} / \mathrm{m} 2) \\
(N=1635)\end{array}$ & $\begin{array}{l}\text { Obese } \\
\text { BMl > 30(kg/m2) } \\
(N=743)\end{array}$ & $p$ value \\
\hline \multicolumn{6}{|l|}{ Medication groups } \\
\hline Antiplatelet therapy & $214(11.8 \%)$ & $12(12.0 \%)$ & $247(15.1 \%)^{a}$ & $122(16.4 \%)^{a}$ & 0.005 \\
\hline Anticoagulant therapy & $59(3.3 \%)$ & $5(5.0 \%)$ & $62(3.8 \%)$ & $35(4.7 \%)$ & 0.31 \\
\hline Bblockers & $165(9.1 \%)$ & $13(13.0 \%)$ & $225(13.8 \%)^{a}$ & $116(15.6 \%)^{a}$ & $<0.001$ \\
\hline Calcium channel blockers & $66(3.6 \%)$ & $2(2.0 \%)$ & $80(4.9 \%)^{a}$ & $58(7.8 \%)^{a}$ & $<0.001$ \\
\hline Angiotensin-converting enzyme inhibitors & $103(5.7 \%)$ & $4(4.0 \%)$ & $123(7.5 \%)^{a}$ & $78(10.5 \%)^{a}$ & $<0.001$ \\
\hline Angiotensin-II receptor antagonists & 58 (3.2 \%) & $1(1.0 \%)$ & $118(7.2 \%)^{a}$ & $72(9.7 \%)^{a}$ & $<0.001$ \\
\hline Statins & $195(10.7 \%)$ & $10(10.0 \%)$ & $238(14.6 \%)^{a}$ & $141(19.0 \%)^{a}$ & $<0.001$ \\
\hline Diuretics & $199(11.0 \%)$ & $13(13.0 \%)$ & $252(15.4 \%)^{a}$ & $147(19.8 \%)^{a}$ & $<0.001$ \\
\hline Nitrates & $90(5.0 \%)$ & $3(3.0 \%)$ & $119(7.3 \%)^{a}$ & $42(5.7 \%)$ & 0.018 \\
\hline Pulmonary medication & 86 (4.7 \%) & $4(4.0 \%)$ & $71(4.3 \%)$ & 48 (6.5 \%) & 0.153 \\
\hline
\end{tabular}

${ }^{a}$ Significantly different $(p<.05)$ compared to normal weight 
Table 3 Postoperative Outcome within 30 Days

\begin{tabular}{|c|c|c|c|c|c|}
\hline & $\begin{array}{l}\text { Normal weight } \\
\text { BMI } 18.5-25(\mathrm{~kg} / \mathrm{m} 2) \\
(\mathrm{N}=1815)\end{array}$ & $\begin{array}{l}\text { Underweight } \\
\mathrm{BMI}<18.5(\mathrm{~kg} / \mathrm{m} 2) \\
(\mathrm{N}=100)\end{array}$ & $\begin{array}{l}\text { Overweight } \\
\text { BMI } 25-30(\mathrm{~kg} / \mathrm{m} 2) \\
(N=1635)\end{array}$ & $\begin{array}{l}\text { Obese } \\
\text { BMI > 30(kg/m2) } \\
(N=743)\end{array}$ & $p$ value \\
\hline Wound infection & $87(4.8 \%)$ & $11(11.0 \%)^{a}$ & $127(7.8 \%)^{\mathrm{a}}$ & $81(10.9 \%)^{a}$ & $P<0.001$ \\
\hline Pneumonia & $31(1.7 \%)$ & $4(4.0 \%)$ & $41(2.5 \%)$ & $16(2.2 \%)$ & $P=0.231$ \\
\hline $\begin{array}{l}\text { Deep vein thrombosis and/or } \\
\text { pulmonary embolism }\end{array}$ & $7(0.4 \%)$ & $1(1.0 \%)$ & $5(0.3 \%)$ & $5(0.7 \%)$ & $P=0.474$ \\
\hline ICU admission & $232(12.8 \%)$ & $27(27.0 \%)^{a}$ & $198(12.1 \%)$ & $95(12.8 \%)$ & $P<0.001$ \\
\hline Reoperation & $87(4.8 \%)$ & $11(11.0 \%)^{\mathrm{a}}$ & $72(4.4 \%)$ & $39(5.2 \%)$ & $P=0.028$ \\
\hline Readmission & $57(3.1 \%)$ & $5(5.0 \%)$ & $67(4.1 \%)$ & $34(4.6 \%)$ & $P=0.246$ \\
\hline Length of hospital stay (days) (median + IQR) & $3(1-8)$ & $7(3-16)^{a}$ & $2(1-7)^{a}$ & $2(1-7)$ & $P<0.001$ \\
\hline Operation time (minutes) (median + IQR) & $39(24-65)$ & $41(27-90)$ & $41(26-66)$ & $50(27-80)^{a}$ & $P<0.001$ \\
\hline Blood loss $(m L)^{b}$ (median + IQR) & $10(5-50)$ & $25(5-138)^{a}$ & $15(5-50)$ & $20(10-100)^{a}$ & $P<0.001$ \\
\hline 30 days mortality & $27(1.5 \%)$ & $4(4.0 \%)$ & $11(0.7 \%)^{a}$ & $10(1.3 \%)$ & $P=0.008$ \\
\hline Cardiovascular complication & $67(3.7 \%)$ & $4(4.0 \%)$ & $53(3.2 \%)$ & $26(3.5 \%)$ & $P=0.897$ \\
\hline Any complication & $339(18.7 \%)$ & $28(28.0 \%)$ & $345(21.1 \%)$ & $185(24.9 \%)$ & $P=0.001$ \\
\hline
\end{tabular}

${ }^{a}$ Significantly different $(p<.05)$ compared to normal weight

${ }^{\mathrm{b}}$ Data was available in $84.3 \%$ of patients

and long-term survival, also known as the obesity paradox. Increased awareness of both the surgeon and the anesthesiologist of obesity related health hazards might have contributed to improved perioperative care [23, 24]. Another explanation could be that obese patients are less often referred for major surgery, leading to election bias.

When compared to patients of normal weight, the underweight patients had a higher ASA classification and a higher risk of postoperative complications. It should be noted however that the underweight patients represent a rather small number of the total study population and results, especially short-term complications, should be interpreted with caution. In the present study, a bigger proportion of patients who underwent

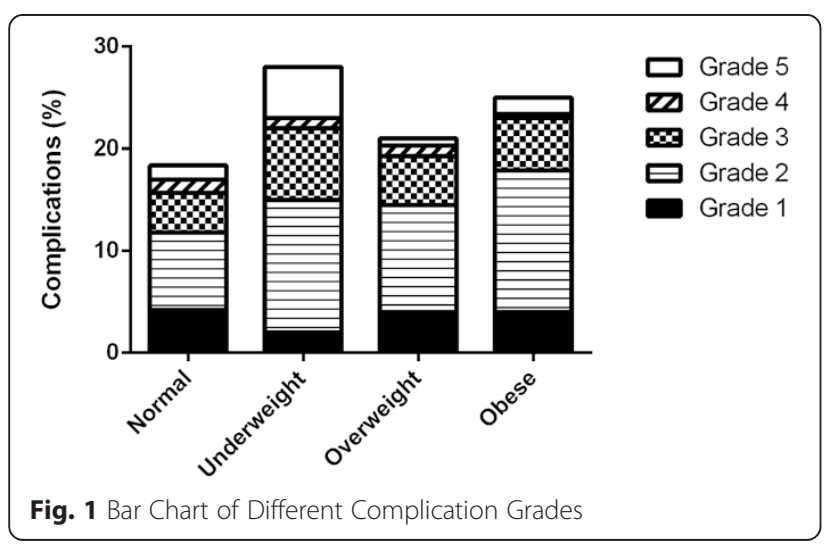

high-risk surgery were underweight, although not statistically significant. The underweight group contained more smokers, a potential confounder, since smoking is associated with wound infection, weight loss and chronic diseases $[25,26]$. Also recent weight loss of more then $10 \%$ or low serum albumin levels are known predictors of postoperative morbidity and mortality [27-29]. With the hypothesis that cachexia might be related to an unhealthy lifestyle or non-compliance, we compared the use of medication between the different BMI groups. We conclude that there was no undertreatment of pulmonary or cardiovascular medication in the underweight group. Unlike we expected, the incidence of malignant disease was not different between underweight and normal weight patients, which might again be explained by a relatively small sample size of the underweight group. Besides complications, we focused on postoperative mortality and long-term prognosis. Our study supports recent data and shows a significantly higher mortality rate for the lowest of BMI rankings [30].

This study has a few potential limitations that must be addressed. First, the recorded data on height and weight were partially self-reported, although this can be considered as a reliable estimate of BMI [31]. There might be a bias in referral pattern, since patients with major comorbidities and the super obese are usually seen in a tertiary hospital. With the prevalence of obesity in our study population being almost twice as high as in the Dutch population, this might not be an important bias [2]. Furthermore, we restricted analyses to patient's first 
Table 4 Univariate and Multivariate Associations of BMl-categories and Complications/Mortality

\begin{tabular}{|c|c|c|c|c|c|c|}
\hline \multirow[b]{2}{*}{ BMl-categories } & \multirow[b]{2}{*}{$\begin{array}{l}N \\
(\%)\end{array}$} & \multicolumn{2}{|c|}{30 days complications } & \multicolumn{3}{|c|}{ Long-term mortality } \\
\hline & & OR $(95 \% \mathrm{Cl})$ & $\begin{array}{l}\text { Adjusted* } \\
\text { OR }(95 \% \text { Cl) }\end{array}$ & $\begin{array}{l} \\
(\%)\end{array}$ & $\begin{array}{l}\text { HR } \\
(95 \% \mathrm{Cl})\end{array}$ & $\begin{array}{l}\text { Adjusted* } \\
\text { HR }(95 \% \text { Cl) }\end{array}$ \\
\hline $\begin{array}{l}\text { Normal weight } \\
\text { BMI 18.5-25 (kg/m2) }\end{array}$ & $334(18.4)$ & 1 & 1 & 331 (18.6) & 1 & 1 \\
\hline $\begin{array}{l}\text { Underweight } \\
\mathrm{BMl}<18.5(\mathrm{~kg} / \mathrm{m} 2)\end{array}$ & $28(28.0)$ & $1.67(1.05-2.63)$ & $1.20(0.73-1.97)$ & $35(35.4)$ & $2.14(1.51-3.05)$ & $2.07(1.44-2.96)$ \\
\hline $\begin{array}{l}\text { Overweight } \\
\text { BMl 25-30 (kg/m2) }\end{array}$ & $343(21.0)$ & $1.17(0.99-1.38)$ & $1.14(0.95-1.36)$ & $212(13.2)$ & $0.68(0.58-0.81)$ & $0.63(0.53-0.75)$ \\
\hline $\begin{array}{l}\text { Obese } B M I>30 \\
(\mathrm{~kg} / \mathrm{m} 2)\end{array}$ & $186(25.0)$ & $1.46(1.19-1.79)$ & $1.31(1.05-1.65)$ & $109(14.8)$ & $0.77(0.62-0.96)$ & $0.71(0.56-0.89)$ \\
\hline
\end{tabular}

a Potential confounders: age, gender, surgical risk, type of anesthesia, ASA classification, diabetes, hypertension, pulmonary -, cardiac - or cerebrovascular disease and the presence of malignancy

operation. Repeated surgery within the study period was often performed because of the same illness; for example a sentinel node procedure, followed by a mastectomy in the next hospital stay. A sensitivity analysis showed no difference in crude or adjusted estimates when including all duplicate cases. We did not have a direct measurement of central (or visceral) adiposity. Instead we used BMI as an indicator of adiposity, but the BMI is unable to distinguish between different kinds of body mass [32, 33].

The surgical procedures in this study have been performed eight up to nine years ago. Advances in clinical medicine can alter current practice. Finally, due to the observational character, this study is inherent to unmeasured confounding.

\section{Conclusion}

In conclusion, our findings suggest that a tendency to consider obesity as a major risk factor in general surgery is not

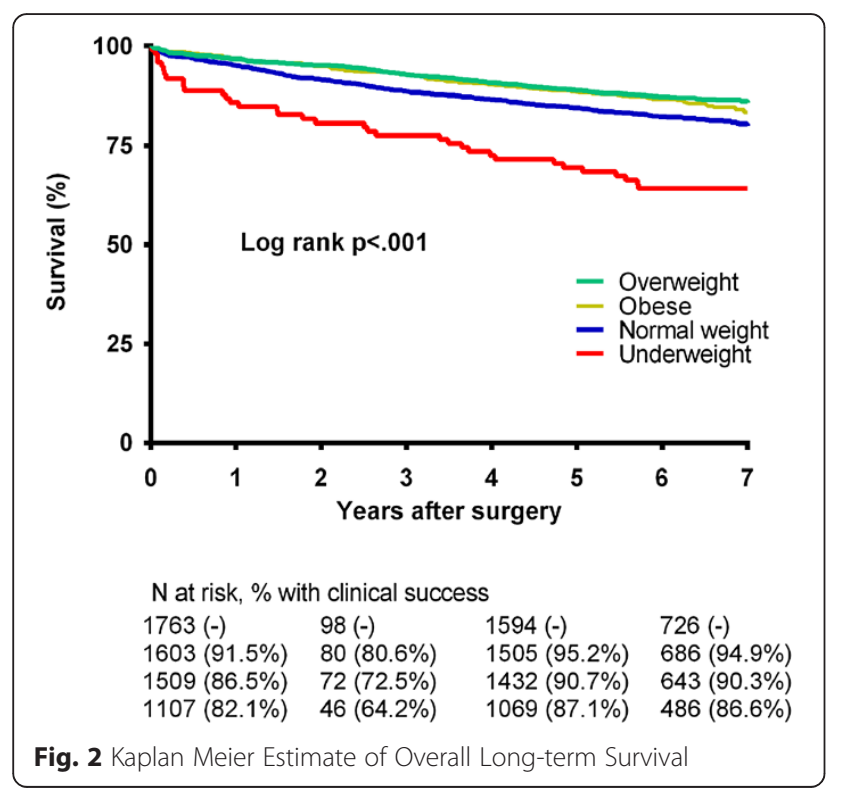

justified. It is the underweight patient who is most at risk of major postoperative complications, including long-term mortality.

\section{Additional file}

Additional file 1: Resume table with complications divided in

different complication groups. (DOCX $52 \mathrm{~kb}$ )

\section{Abbreviations used}

ASA: American Society of Anesthesiologists; BMl: Body mass index; COPD: Chronic obstructive pulmonary disease; HR: Hazard ratio; ICU: Intensive care unit; IQR: Interquartile range; LOS: Length of hospital stay; OR: Odds ratio; SD: Standard deviation.

\section{Competing interests}

The authors declare that they have no competing interests.

\section{Authors' contributions}

ET was responsible for data collection, statistical analysis and interpretation, wrote the manuscript. SH interpreted and supervised statistical analysis and edited the manuscript. SB and T.V. acquired data. AH supervised data collection and interpretation, edited the manuscript. RJS supervised interpretation and edited the manuscript. All authors approved of this submitted version of the article.

\section{Author details}

'Department of anesthesiology, Erasmus University Medical Centre, Room H-1273, PO Box 2040, 3000, CA, Rotterdam, The Netherlands. ${ }^{2}$ Department of surgery, Orbis Medical Centre, Sittard, The Netherlands.

Received: 20 October 2014 Accepted: 22 July 2015

Published online: 31 July 2015

\section{References}

1. Obesity: preventing and managing the global epidemic. Report of a WHO consultation. World Health Organ Tech Rep Ser. 2000;894:i-xii, 1-253.

2. Berghofer A, Pischon T, Reinhold T, Apovian CM, Sharma AM, Willich SN. Obesity prevalence from a European perspective: a systematic review. BMC Public Health. 2008:8:200.

3. Haslam DW, James WP. Obesity. Lancet. 2005;366(9492):1197-209.

4. Livingston $\mathrm{EH}, \mathrm{Ko} \mathrm{CY}$. Use of the health and activities limitation index as a measure of quality of life in obesity. Obes Res. 2002;10(8):824-32.

5. Berrington de Gonzalez A, Hartge P, Cerhan JR, Flint AJ, Hannan L, Maclnnis RJ, et al. Body-mass index and mortality among 1.46 million white adults. N Engl J Med. 2010;363(23):2211-9.

6. Flegal KM, Graubard BI, Williamson DF, Gail MH. Excess deaths associated with underweight, overweight, and obesity. JAMA. 2005;293(15):1861-7. 
7. Manson JE, Willett WC, Stampfer MJ, Colditz GA, Hunter DJ, Hankinson SE, et al. Body weight and mortality among women. N Engl J Med. 1995:333(11):677-85.

8. Dindo D, Muller MK, Weber M, Clavien PA. Obesity in general elective surgery. Lancet. 2003;361(9374):2032-5.

9. Klasen J, Junger A, Hartmann B, Jost A, Benson M, Virabjan T, et al. Increased body mass index and peri-operative risk in patients undergoing non-cardiac surgery. Obes Surg. 2004;14(2):275-81.

10. Tichansky DS, DeMaria EJ, Fernandez AZ, Kellum JM, Wolfe LG, Meador JG, et al. Postoperative complications are not increased in super-super obese patients who undergo laparoscopic Roux-en-Y gastric bypass. Surg Endosc. 2005;19(7):939-41.

11. Oreopoulos A, Padwal R, Norris CM, Mullen JC, Pretorius V, Kalantar-Zadeh K. Effect of obesity on short- and long-term mortality postcoronary revascularization: a meta-analysis. Obesity (Silver Spring). 2008;16(2):442-50.

12. Mullen JT, Moorman DW, Davenport DL. The obesity paradox: body mass index and outcomes in patients undergoing nonbariatric general surgery. Ann Surg. 2009;250(1):166-72.

13. Valentijn TM, Galal W, Hoeks SE, van Gestel YR, Verhagen HJ, Stolker RJ. Impact of obesity on postoperative and long-term outcomes in a general surgery population: a retrospective cohort study. World J Surg. 2013;37(11):2561-8.

14. Boersma E, Kertai MD, Schouten O, Bax JJ, Noordzij P, Steyerberg EW, et al. Perioperative cardiovascular mortality in noncardiac surgery: validation of the Lee cardiac risk index. Am J Med. 2005;118(10):1134-41.

15. Clavien PA, Sanabria JR, Strasberg SM. Proposed classification of complications of surgery with examples of utility in cholecystectomy. Surgery. 1992;111(5):518-26.

16. Dindo D, Demartines N, Clavien PA. Classification of surgical complications: a new proposal with evaluation in a cohort of 6336 patients and results of a survey. Ann Surg. 2004;240(2):205-13.

17. Mullen JT, Davenport DL, Hutter MM, Hosokawa PW, Henderson WG, Khuri SF, et al. Impact of body mass index on perioperative outcomes in patients undergoing major intra-abdominal cancer surgery. Ann Surg Oncol. 2008;15(8):2164-72.

18. Kurmann A, Vorburger SA, Candinas D, Beldi G. Operation time and body mass index are significant risk factors for surgical site infection in laparoscopic sigmoid resection: a multicenter study. Surg Endosc. 2011;25(11):3531-4.

19. House MG, Fong Y, Arnaoutakis DJ, Sharma R, Winston CB, Protic M, et al. Preoperative predictors for complications after pancreaticoduodenectomy: impact of BMI and body fat distribution. J Gastrointest Surg. 2008;12(2):270-8.

20. Hopf HW, Hunt TK, West JM, Blomquist P, Goodson 3rd WH, Jensen JA, et al. Wound tissue oxygen tension predicts the risk of wound infection in surgical patients. Arch Surg. 1997;132(9):997-1004. discussion 1005.

21. Tanaka S, Inoue S, Isoda F, Waseda M, Ishihara M, Yamakawa T, et al. Impaired immunity in obesity: suppressed but reversible lymphocyte responsiveness. Int J Obes Relat Metab Disord. 1993;17(11):631-6.

22. Stryker LS, Abdel MP, Morrey ME, Morrow MM, Kor DJ, Morrey BF. Elevated postoperative blood glucose and preoperative hemoglobin A1C are associated with increased wound complications following total joint arthroplasty. J Bone Joint Surg Am. 2013;95(9):808-14, S801-802.

23. De Hert S, Imberger G, Carlisle J, Diemunsch P, Fritsch G, Moppett I, et al. Preoperative evaluation of the adult patient undergoing non-cardiac surgery: guidelines from the European Society of Anaesthesiology. Eur J Anaesthesiol. 2011;28(10):684-722.

24. Buchwald H, Estok R, Fahrbach K, Banel D, Sledge I. Trends in mortality in bariatric surgery: a systematic review and meta-analysis. Surgery. 2007;142(4):621-32; discussion 632-5.

25. Galal W, van Gestel YR, Hoeks SE, Sin DD, Winkel TA, Bax JJ, et al. The obesity paradox in patients with peripheral arterial disease. Chest. 2008;134(5):925-30.

26. Willett WC, Dietz WH, Colditz GA. Guidelines for healthy weight. N Engl J Med. 1999;341(6):427-34.

27. Palma S, Cosano A, Mariscal M, Martinez-Gallego G, Medina-Cuadros M, Delgado-Rodriguez M. Cholesterol and serum albumin as risk factors for death in patients undergoing general surgery. Br J Surg. 2007;94(3):369-75.

28. Oh CA, Kim DH, Oh SJ, Choi MG, Noh JH, Sohn TS, et al. Nutritional risk index as a predictor of postoperative wound complications after gastrectomy. World J Gastroenterol. 2012;18(7):673-8.

29. Bozzetti F, Gianotti L, Braga M, Di Carlo V, Mariani L. Postoperative complications in gastrointestinal cancer patients: the joint role of the nutritional status and the nutritional support. Clin Nutr. 2007;26(6):698-709.
30. Landi F, Onder G, Gambassi G, Pedone C, Carbonin P, Bernabei R. Body mass index and mortality among hospitalized patients. Arch Intern Med. 2000;160(17):2641-4.

31. Kuskowska-Wolk A, Karlsson P, Stolt M, Rossner S. The predictive validity of body mass index based on self-reported weight and height. Int J Obes. 1989;13(4):441-53.

32. Gallagher D, Visser M, Sepulveda D, Pierson RN, Harris T, Heymsfield SB. How useful is body mass index for comparison of body fatness across age sex, and ethnic groups? Am J Epidemiol. 1996;143(3):228-39.

33. Romero-Corral A, Somers VK, Sierra-Johnson J, Thomas RJ, Collazo-Clavell $\mathrm{ML}$, Korinek J, et al. Accuracy of body mass index in diagnosing obesity in the adult general population. Int J Obes (Lond). 2008;32(6):959-66.

\section{Submit your next manuscript to BioMed Central and take full advantage of:}

- Convenient online submission

- Thorough peer review

- No space constraints or color figure charges

- Immediate publication on acceptance

- Inclusion in PubMed, CAS, Scopus and Google Scholar

- Research which is freely available for redistribution 